\title{
PROSES REHABILITASI SOSIAL WANITA TUNA SUSILA DI BALAI REHABILITASI SOSIAL KARYA WANITA (BRSKW) PALIMANAN KABUPATEN CIREBON
}

\author{
OLEH: \\ WIDYA SUCI RAMADHANI ${ }^{1}$, SRI SULASTRI ${ }^{2}$, H. SONI AKHMAD NURHAQIM ${ }^{3}$ \\ 1. Mahasiswa Program Studi Sarjana (S-1) Kesejahteraan Sosial Fakultas Ilmu Sosial dan Ilmu Politik \\ Universitas Padjadjaran \\ 2. Departemen Kesejahteraan Sosial Fakultas Ilmu Sosial dan Ilmu Politik Universitas Padjadjaran \\ 3. Departemen Kesejahteraan Sosial Fakultas IImu Sosial dan IImu Politik Universitas Padjadjaran \\ E-mail: \\ widyasr97@gmail.com,ati.sukaati@gmail.com,soni.nulhaqim@unpad.ac.id
}

\begin{abstract}
ABSTRAK
Masalah pelacuran atau prostitusi merupakan masalah sosial yang sangat kompleks karena populasi setiap tahunnya masih terlihat sangat banyak. Kemudian perilaku para pekerja pelacuran merupakan hal yang sangat bertentangan dengan norma dan nilai yang berlaku didalam masyarakat. Oleh karena itu perlu adanya penanganan yang serius untuk merespon permasalahan ini. Rehabilitasi sosial adalah salah satu intervensi yang dapat digunakan untuk mengatasi permasalahan wanita tuna susila (WTS). Rehabilitasi sosial juga merupakan ranah praktik pekerjaan sosial, maka dari itu perlu adanya kontribusi dari pekerja sosial dalam penanganan masalah tersebut. Salah satu lembaga pemerintah yang melaksakan fungsi rehabilitasi sosial adalah Balai Rehabilitasi Sosial Karya Wanita (BRSKW) Palimanan Kabupaten Cirebon. Adapun waktu rehabilitasi dilakukan kurang lebih selama enam bulan. Dari hal tersebut penulis tertarik untuk meneliti proses rehabilitasi yang dilakukan oleh pihak lembaga, dan hasil dari proses rehabilitasi tersebut. Karena pada kebanyakan kasus para WTS yang sudah mengikuti rehabilitasi akan kembali lagi menjadi WTS.
\end{abstract}

Kata kunci: prostitusi, wanita tuna susila, rehabilitasi sosial, pekerja sosial 


\section{PENDAHULUAN}

Prostitusi bukanlah hal yang asing ditelinga masyarakat Indonesia. Kini prostitusi menjadi sebuah masalah sosial yang semakin kompleks. Terlebih kecanggihan teknologi dapat berpengaruh terhadap perkembangan bentuk dan tingkatannya. Kebanyakan para pekerja ditempat prostitusi adalah wanita atau sering disebut dengan istilah wanita tuna susila (WTS) . Masalah wanita tuna susila merupakan masalah sosial, karena perbuatan tersebut menyimpang dari norma-norma atau nilai di masyarakat.

Berdasarkan data dari Pusat Data Informasi Kesejahteraan Sosial Kemensos RI tahun 2015, populasi wanita tuna susila seluruh Indonesia pada tahun 2000 sebanyak 73.037 orang, pada tahun 2003 sebanyak 81.893 orang dan per Maret 2015 masih terdapat 64. 435 wanita Indonesia yang menjadi WTS di lokalisasi legal maupun ilegal. Sedangkan berdasarkan data dari Sub Dinas Bina Program populasi yang dipublikasikan oleh BRSKW Palimanan, wanita tuna susila di Jawa Barat sampai dengan tahun 2006 berjumlah 5598 orang, dan tiap tahun cenderung selalu meningkat.

Walaupun sumber data yang didapat masih pada tahun-tahun sebelumnya, namun dari data tersebut dapat dilihat bahwa populasi wanita tuna susila setiap tahunnya tidak menunjukkan penurunan yang sangat drastis. Banyaknya jumlah populasi WTS dapat disebabkan oleh beberapa faktor yang diantaranya faktor kemiskinan, pendidikan yang rendah, kemalasan, dan kurangnya keahlian. Padahal permasalahan mengenai wanita tuna susila harus ditangani secara serius. Pasalnya dampak dari permasalahan tersebut berakibat pada munculnya berbagai tindak kriminal, dan penyakit menular seksual, khususnya HIV/AIDS.

Untuk merespon permasalahan tersebut, maka pemerintah mengeluarkan kebijakan untuk melakukan rehabilitasi dan resosialisasi kepada para tuna sosial khususnya wanita tuna susila. Adapun yang dimaksud dengan rehabilitasi dalam hal ini yaitu suatu tahap bimbingan dan pembinaan yang diberikan oleh suatu lembaga bagi para wanita tuna susila (WTS). Rehabilitasi sosial dimaksudkan untuk memulihkan dan mengembangkan kemandirian dan kemampuan klien atau penyandang masalah sosial agar dapat melaksanakan fungsi sosial secara optimal dalam kehidupan masyarakat. Tujuan rehabilitasi sosial sebagaimana dikemukakan Soenaryo (1995 : 118) adalah :

"pertama memulihkan kembali rasa harga diri, percaya diri, kesadaran serta tanggung jawab terhadap masa depan diri, keluarga maupun masyarakat atau lingkungan sosialnya, kedua memulihkan kembali kemauan dan kemampuan untuk dapat dilaksanakan fungsi sosialnya secara wajar."

Salah satu lembaga pemerintah yang melaksanakan program rehabilitasi adalah Balai Rehabilitasi Sosial Karya Wanita (BRSKW) Palimanan Kabupaten Cirebon. Merujuk pada rehabilitasi, sudah ada beberapa penelitian yang membahas persoalan tersebut. Seperti penelitian yang dilakukan oleh Ikas Adinta dengan judul penelitian "Efektivitas Pelayanan dan Rehabilitasi Sosial Untuk Mewujudkan Keberfungsian Sosial Klien di Panti Sosial Karya Wanita (PSKW) Mulya Jaya". Hasil dari penelitian tersebut mengatakan bahwa proses rehabilitasi sudah berjalan dengan baik, namun untuk keefektivitasan sendiri masih sangat bergantung pada kemauan klien dan pengaruh lingkungannya.

Melihat hasil penelitian tersebut, peneliti memiliki ketertarikan untuk meneliti proses rehabilitasi yang dilakukan oleh lembaga lain, karena pada kenyataannya masih banyak ditemukan kasus WTS yang sudah beberapa kali keluar masuk panti rehabilitasi.

Adapun pentingnya dilakukan penelitian ini karena rehabilitasi sosial merupakan suatu usaha kesejahteraan sosial yang termasuk ranah pekerjaan sosial.

\section{METODE}

\section{Pendekatan Penelitian}

Penelitian ini dilakukan dengan menggunakan pendekatan kualitatif. Pendekatan kualitatif bertujuan untuk menjelaskan fenomena dengan sedalamdalamnya melalui pengumpulan data. Seperti yang dikatakan oleh Creswell dalam Bambang, (2015:12) pendekatan kualitatif adalah suatu proses penelitian dan pemahaman yang berdasarkan pada metodologi yang menyelidiki suatu fenomena sosial dan masalah manusia. Dari penjelasan tersebut penulis berpendapat bahwa pendekatan kualitatif adalah proses 
penelitian yang menyajikan data secara deskriptif mengenai fenomena sosial secara sejelas-jelasnya.

Menurut peneliti, pendekatan kualitatif adalah pendekatan yang cocok untuk digunakan dalam penelitian yang akan dilakukan. Karena hasil akhir dari penelitian ini akan mendeskripsikan dan menggambarkan fenomena yang terjadi dalam kehidupan sosial sejelas mungkin, khususnya mengenai proses rehabilitasi sosial yang dilakukan oleh Balai Rehabilitasi Sosial karya Wanita Palimanan Kabupaten Cirebon.

\section{Teknik Pengumpulan Data}

Teknik pengumpulan data merupakan cara yang digunakan peneliti untuk mendapatkan data dalam suatu penelitian. Untuk memperoleh data penelitian ada beberapa metode atau teknik yang dilakukan, diantaranya adalah:

Pengumpulan data primer dilakukan dengan menggunakan metode:

1. Wawancara

Peneliti menggunakan teknik wawancara mendalam (in-depth interview) untuk mengumpulkan data mengenai tema penelitian yang diangkat. Hal ini bertujuan untuk mendapatkan informasi yang lebih kompleks dan jelas. Agar wawancara lebih terarah dan data yang didapatkan sesuai dengan yang dibutuhkan, maka diperlukan sebuah instrumen yang berupa pedoman wawancara.

2. Observasi

Metode observasi dilakukan dengan cara mengamati perilaku, kejadian atau kegiatan orang atau sekelompok orang yang diteliti secara langsung maupun tidak langsung, kemudian mencatat hasil pengamatan tersebut. Observasi langsung dilakukan dengan cara ikut turun langsung ke lapangan untuk mengetahui kondisi yang sebenarnya. Observasi yang dilakukan secara langsung terkait penelitian ini adalah asesmen yang dilakukan oleh informan dalam BRSKW Palimanan Kabupaten Cirebon.

3. Studi Dokumentasi

Metode ini dilakukan dengan mencari dokumen atau arsip-arsip yang relevan terkait tema penelitian. Dokumen dapat berupa foto-foto, pedoman umum, jurnaljurnal ilmiah dan lain sebagainya yang terkait dengan penelitian.

\section{TINJAUAN PUSTAKA}

\section{Prostitusi}

Menurut Profesor W.A Bonger prostitusi ialah gejala kemasyarakatan di mana wanita menjual diri melakukan perbuatanperbuatan seksual sebagai mata pencaharian. Bonger juga menjelaskan bahwa ada beberapa unsur dalam pelacuran, unsur pertama adalah motif ekonomis, dan unsur kedua pelacuran bersifat mata pencaharian (beroepsmatig); suatu jalan untuk mencari nafkah. Jika tidak ada kedua unsur tersebut maka belum bisa dikatakan sebagai pelacuran (Simandjuntak, 1981).

Berbicara mengenai prostitusi, erat kaitannya dengan wanita tuna susila. Wanita tuna susila merupakan sebutan bagi para wanita pekerja seks atau para wanita yang bekerja dalam prostitusi. Adapun Peraturan Pemerintah Daerah DKI Jakarta Raya tahun 1967 mengenai penanggulangan masalah pelacuran, menyatakan bahwa wanita tuna susila adalah wanita yang mempunyai kebiasaan melakukan hubungan kelamin di luar perkawinan, baik dengan imbalan jasa maupun tidak. Sedangkan menurut Peraturan Pemerintah Daerah Tingkat I Jawa Barat pelacur atau yang disingkat $\mathrm{P}$, adalah mereka yang melakukan hubungan kelamin di luar pernikahan yang sah.

Adapun pengertian WTS menurut Soedjono (1977) adalah sebagai berikut :

"Wanita Tuna Susila atau wanita pelacur adalah wanita yang menjual tubuhnya untuk memuaskan seksual laki - laki siapapun yang menginginkannya, dimana wanita tersebut menerima sejumlah uang atau barang (umumnya dengan uang dari laki-laki pemakaianya).

Seperti yang diulas dalam latar belakang, ada beberapa faktor yang menyebabkan seseorang menjadi wanita tuna susila (Kartono, 2014):

1. Salah satu faktor yang membuat wanita menjadi seorang tuna susila adalah untuk menghindarkan diri dari kesulitan hidup, dan mendapatkan kesenangan melalui jalan pendek. Faktor lainnya adalah kurangnya 
pengertian, pendidikan, dan buta huruf, sehingga menghalalkan pelacuran.

2. Untuk menjadi seorang pekerja seks tidak memerlukan keterampilan/skiil, tidak memerlukan intelegensi tinggi, mudah dikerjakan. Modal utama dari pekerjaan ini hanyalah kecantikan, dan keberanian.

3. Tekanan ekonomi, faktor kemiskinan, ada pertimbangan-pertimbangan ekonomis untuk mempertahankan kelangsungan hidupnya.

\section{Rehabilitasi Sosial}

Dalam Undang-Undang No. 11 Tahun 2009 mengenai Kesejahteraan Sosial diatur mengenai rehabilitasi sosial sebagai penyelenggaraan kesejahteraan sosial, adapun pengertian dari rehabilitasi sosial menurut Undang-Undang No. 11 Tahun 2009:

"Rehabilitasi sosial dimaksudkan untuk memulihkan dan mengembangkan kemampuan seseorang yang mengalami disfungsi sosial agar dapat melaksanakan fungsi sosialnya secara wajar. Rehabilitasi sosial yang dimaksud dapat dilaksanakan secara persuasif, motivatif, koersif, baik dalam keluarga, masyarakat maupun panti sosial."

Rehabilitasi sosial merupakan suatu upaya untuk mengembalikan atau memperbaiki keadaan dan keberfungsian sosial seseorang. Adapun definisi rehabilitasi sosial menurut Supiadi (dalam Maryami, dkk: 2015):

"Rehabilitasi sosial adalah segenap upaya yang ditujukan untuk mengintegrasikan kembali seseorang kedalam kehidupan masyarakat dengan cara membantunya menyesuaikan diri dengan tuntutan keluarga, komunitas dan pekerjaan sejalan dengan pengurangan setiap beban sosial dan ekonomi yang dapat merintangi proses rehabilitasi."

Berbeda dengan Supiadi, menurut Nitimihardja (2004):

$\begin{array}{lll}\text { "Rehabilitasi sosial merupakan } & \text { upaya } \\ \text { yang bertujuan } & \text { untuk } \\ \text { mengintegrasikan seseorang } & \text { yang }\end{array}$

mengalami masalah sosial dalam kehidupan masyarakat dimana ia berada. Pengintegrasian tersebut dapat dilakukan melalui upaya peningkatan penyesuaian diri, baik terhadap keluarga, komunitas, maupun pekerjanya.

Adapun proses rehabilitasi sosial yang seharusnya dilakukan oleh setiap panti menurut Badiklit Kesos, 2004, meliputi (1) Tahap Pendekatan Awal, (2) Tahap Pengungkapan dan Pemahaman masalah (Assesmen), (3) Tahap perencanaan program pelayanan, (4) Tahap pelaksanaan pelayanan, (5) Tahap pasca pelayanan rehabilitasi sosial.

\section{Perspektif Pekerjaan Sosial}

Rehabilitasi sosial merupakan salah satu ranah praktik pekerjaan sosial. Seperti yang dijabarkan dalam Wibhawa (2010) bahwa peran pekerjaan sosial diantaranya yaitu (1) meningkatkan kapasitas orang dalam mengatasi masalah yang dihadapinya, (2) menggali dan menghubungkan sumber-sumber yang tersedia di sekitar klien, (3) meningkatkan jaringan pelayanan sosial, dan (4) Mengoptimalan keadilan sosial melalui pengembangan kebijakan sosial.

Untuk isu penelitian ini pekerja sosial memiliki peran dalam memberikan pelayanan sosial kepada para klien (wanita tuna susila) dengan cara turut serta dalam pelaksanaan rehabilitasi sosial. Adapun maksud dalam rehabilitasi sosial ini adalah suatu upaya untuk memulihkan dan mengembangkan kemampuan seseorang yang mengalami disfungsi sosial agar dapat melaksanakan fungsi sosialnya secara wajar.

\section{PEMBAHASAN}

Prostitusi merupakan salah satu masalah sosial yang setiap tahun semakin kompleks. Keberadaan wanita tuna susila sebagai para pekerja seks yang bekerja di lokasi prostitusi harus segera diatasi keberadaanya. Hal tersebut dikarenakan banyak dampak negatif yang disebabkan karena pekerjaan tersebut baik bagi pelakunya maupun masyarakat.

Salah satu cara atau intervensi yang dilakukan untuk mengatasi permasalahan WTS adalah dengan melakukan rehabilitasi kepada para WTS. Seperti yang telah dijelaskan bahwa 
rehabilitasi sosial dimaksudkan untuk memulihkan dan mengembangkan kemampuan seseorang yang mengalami disfungsi sosial agar dapat melaksanakan fungsi sosialnya secara wajar.

Nantinya para WTS akan diberikan bimbingan moral, fisik, mental, maupun pendidikan atau keterampilan. Adapun rehabilitasi sosial yang dilakukan oleh lembaga terdiri dari beberapa proses dan tahapan, untuk lembaga BRSKW Palimanan-Cirebon, rehabilitasi tersebut dilakukan selama kurang lebih 6 (enam) bulan. Adapun proses rehabilitasi sosial pada umumnya dilaksanakan dalam beberapa tahap: tahap pendekatan awal, tahap assessment, tahap perencanaan program pelayanan, tahap pelaksanaan pelayanan, dan tahap pasca pelayanan rehabilitasi sosial.

\section{KESIMPULAN}

Prostitusi dan pelacuran adalah masalah sosial yang semakin kompleks. Hal tersebut dipicu oleh beberapa faktor, seperti faktor kemikinan, kurangnya pendidikan, dan tidak memiliki keahlian. Salah satu intervensi yang dapat dilakukan adalah dengan rehabilitasi sosial. Rehabilitasi sosial ini bertujuan untuk mengembalikan keberfungsian para eks WTS ke lingkungan sosialnya, selain itu rehabilitasi juga bertujuan untuk memberikan keterampilan dan keahlian pada para WTS agar tidak kembali pada dunia prostitusi. Peran pekerja sosial dibutuhkan dalam hal ini, karena rehabilitasi sosial adalah salah satu ranah praktik pekerjaan sosial.

\section{DAFTAR PUSTAKA}

Badan Pendidikan dan Penelitian Kesejahteraan Sosial. (2004). Standarisasi Panti Sosial. Jakarta: Badan Pendidikan dan Penelitian Kesos Kementrian Sosial RI
Dirdjosisworo, Soedjono. 1997. Pelacuran Ditinjau dari Segi Hukum dan Kenyataan dalam Masyarakat. Bandung: Karya Nusantara.

Kartono, Kartini. 2014. Patologi Sosial. Jakarta: Rajawali Pers.

Maryami, Amy, dkk. 2015. Peran Lembaga Kesejahteraan Sosial Dalam Penanganan Penyalahgunaan Napza Di Jawa Barat. Jurnal IImiah Pekerjaan Sosial, Volume 14 Nomor 1. Bandung: Sekolah Tinggi Kesejahteraan Sosial Bandung

Nitimihardja, 2004. Rehabilitasi Sosial dalam Jaminan Sosial (Isu-Isu Tematik Pembangunan Sosial Konsepsi dan Strategi. Jakarta: Balatbangsos.

Raharjo, ST. 2015. Assessment untuk Praktik Pekerjaan Sosial dan Kesejahteraan Sosial. Bandung: Unpad Press 2015. Dasar Pengetahuan Pekerjaan Sosial. Bandung: Unpad Press. 2015. Keterampilan Pekerjaan Sosial: Dasar-dasar. Bandung, Unpad Press.

Rustanto, Bambang. 2015. Penelitian Kualitatif Pekerjaan Sosial. Bandung: PT Remaja Rosdakarya

Simandjuntak. 1981. Pengantar Kriminologi dan Patologi Sosial. Bandung: Tarsito.

Sunaryo.1995. Dasar-Dasar Rehabilitasi dan Pekerjaan Sosial. Jakarta: Depdikbud Dirjen Dikti PPTG.

Wibhawa, Budhi., dkk. 2010. Dasar-Dasar Pekerjaan Sosial. Bandung: Widya Padjadjaran. 